Mycologia, 84(6), 1992, pp. 901-910.

(C) 1992, by The New York Botanical Garden, Bronx, NY 10458-5126

\title{
DEVONIAN FUNGI: INTERACTIONS WITH THE GREEN ALGA PALAEONITELLA
}

\author{
ThOMAS N. TAYLOR \\ Department of Plant Biology and Byrd Polar Research Center, \\ The Ohio State University. Columbus, Ohio 43210 \\ AND \\ Hagen Hass and Winfried Remy \\ Forschungsstelle fur Palaobotanik. Westalische Wilhelms-Universitat. \\ D-4400 Münster, Germany \\ ABSTRACT
}

\begin{abstract}
This paper describes three new taxa of fossil aquatic fungi preserved in 400 -million-year-old Lower Devonian Rhynie Chert. All of the fungal morphotypes are attached to cells of the green alga Palaeonitella cranii. Milleromyces rhyniensis is characterized by a holocarpic, epibiotic zoosporangium with an elongate discharge tube that penetrates the host cell wall; arising from the base of the sporangium is an extensive rhizoidal system. Stages in infection by presumed zoospores are documented. In Lyonomyces pyriformis the globose-pyriform thallus is embedded in the surface coating of the cell wall. At the base of each thallus is a single rhizoid. Krispiromyces is extramatrical, holocarpic, and characterized by a short beak-like discharge papilla. The rhizoidal system appears to be apophysate. Some of these fungi were probably saprobes, while others were deemed parasitic because of the extensive hypertrophy of some of the algal cells. Although not all life history stages are represented, the discovery of these Lower Devonian forms greatly expands our knowledge of the biology and diversity of aquatic fungi in an ancient freshwater ecosystem.
\end{abstract}

Key Words: apophysis, chytrid, Devonian, discharge papilla, fossil, hypertrophy, parasite, zoospore

The Lower Devonian (Siegenian) Rhynie Chert represents an important benchmark in biology. It is from this exquisitely preserved fresh water paleoecosystem that Kidston and Lang described several simple sporophytes between 1917 and 1921 that have figured prominently in our understanding of early land plant evolution. In recent years new information has been added about these plants that ranges from details about the conducting elements (Edwards, 1986; Kenrick et al., 1991) to the structure and organization of the gametophytes (Remy and Remy, 1980; Remy and Hass, $1991 \mathrm{a}, \mathrm{b})$. In addition to the terrestrial plants, Kidston and Lang (1921) also described and illustrated several algae and fungi.

The best known alga from the Rhynie site is the charophyte Palaeonitella cranii (Kidston and Lang, 1921; Edwards and Lyon, 1983). It consists of an upright axis bearing regularly spaced whorls of lateral branches, which in turn may produce secondary laterals (FIG. 1). At the base are rhizoids that served to anchor the plant to the substrate. Associated with Palaeonitella in the Rhy- nie Chert are three different aquatic fungi that had various levels of interaction in the ecosystem. Some were probably saprophytic, while others were obvious parasites based on host response. It is the intent of this report to describe these microscopic fungi and to document their interrelationship with Palaeonitella cranii.

\section{MATERIALS AND METHODS}

All three fungi are associated with cells of the green alga Palaeonitella cranii, either attached to the outer surface of the algal cells or penetrating the cell wall. Specimens were studied in thin sections prepared by cementing pieces of Rhynie Chert to standard microscope slides with Lakeside cement, and then grinding the rock to a thickness of 50-150 $\mu \mathrm{m}$ using silicon carbide abrasive powder. Fungal specimens were located and photographed using oil immersion objectives directly on the surface of the rock. Slides are housed in the Paleobotanical Collection of Professor Winfried Remy, Westfalische Wilhelms-Universitat, Forschungsstelle fur Palaobotanik, Munster. Acquisition numbers are noted in the figure descriptions and in the diagnosis of each taxon.

We have provided descriptive diagnoses of the fungi 
reported here despite the fact that we lack detailed information about many features that might be useful in identifying the major group (order) to which these Lower Devonian forms belong. However, the absence of these characters does not detract from the importance of these fossil morphotypes. The realization that fungal structures as small and delicate as apophyses and probable zoospores can be preserved in 400-million-year-old sediments (Taylor et al., 1992b) underscores the necessity of recording these thallus and life history stages accurately in the literature as a foundation for subsequent studies. While some may argue that the introduction of new taxa further burdens an already extensive taxonomy of fungal morphotypes, especially in the case of fossils where additional information may never be added, it is our belief that this is precisely the reason why the fossil record of fungi has been largely ignored and, as a result, has played little in the role of understanding the biology and evolution of these ancient organisms.

Research with living chytrids has demonstrated that many of the characters used to identify various genera and species are highly plastic and can become altered depending on the substrate on which they were grown (Miller, 1976). This had prompted Barr $(1980,1984)$ to utilize zoospore ultrastructure as a basis of characterizing larger taxonomic groups. Although it is possible to record probable flagella in fossil zoospores, it is doubtful that this feature will ever be routinely used to distinguish fossil fungi. Since it is currently not possible to assign the fossils to modern groups, even at the level of the class, we are proposing the form class Paleomastigomycetes as a repository for such fossil, chytrid-like fungi.

\section{TAXONOMY}

Milleromyces Taylor, Hass et Remy, gen. nov. (Diagnosis same as for type species.)

Milleromyces rhyniensis Taylor, Hass et Remy, sp. nov.

FIGS. 2-15

Endobiotic smooth-walled zoosporangium, spherical to globose up to $60 \mu \mathrm{m}$ long with narrow, cylindrical discharge tube slightly thickened at orifice, tube always penetrating cell wall and up to $25 \mu \mathrm{m}$ long and $4 \mu \mathrm{m}$ in diam; rhizoidal system arising from prominent, slightly lateral region on base; hyphae approximately $1 \mu \mathrm{m}$ in diam, near attachment point, becoming extensively branched and more delicate; encysted zoospores 4-6 $\mu \mathrm{m}$ in diam with single refractive inclusion, and infection tube. Resting sporangium not known.

HOLOTYPE. Specimens in slide P 1478, Paleobotanical Collection, W. Remy; FIG. 7 in this paper.

PARATYPES. Specimens in slide 1478 in above collections; Figs. 2-6, 8-15 in this paper.

Collection locality. Rhynie, Aberdeenshire Scotland. National Grid Reference NJ 494276 (Edwards, 1986).

AGE. Lower Devonian.

Stratigraphic POSItIon. Siegenian.

ETYMOLOGY. The generic name Milleromyces is proposed in honor of the late Professor Charles E. Miller, Ohio University, friend, colleague and distinguished scholar of aquatic fungi; the specific epithet rhyniensis refers to the collecting locality.

COMMENTARY. There is a considerable amount of detailed information available about Milleromyces including: encysted zoospores, penetration of the host cell and the mature flask-shaped zoosporangia with the discharge papilla extending from the host cell. On the surface of some Palaeonitella cells are small, spherical to slightly elongate spores that may represent encysted zoospores (FIGs. 2-5). The majority of these range from 3-5 $\mu \mathrm{m}$ in diam, and often appear in slight depressions of the cell wall (FIG. 3). In transmitted light the wall of these spores is approximately the same thickness as the Palaeonitella cell (FIGS. 3,6). A few spores contain an opaque spherical structure that averages approximately $0.3 \mu \mathrm{m}$ in diam (FIGs. 3, 4). It is approximately the same size as the oil or refractive globule present in the zoospores and planogametes of numerous aquatic fungi (Sparrow, 1960).

FIGURE 5 is a section through a cell of Palaeonitella that shows two encysted zoospores on the outside of the cell wall. Immediately beneath each

Figs. 1-10. Fossil fungi and Palaeonitella cranii. 1. Longitudinal section of Palaeonitella cranii showing several whorls of appendages. Slide $2261, \times 150.2-10$. Milleromyces rhyniensis. $C=$ cell wall; $P=$ protoplast. 2. Section through cell showing three encysted zoospores. Slide $1477, \times 1500$. 3. Detail of two zoospores illustrated in FIG. 2; note slight depression and opaque inclusions in one at left. Slide $1477, \times 3000.4$. Section through cell (C) showing zoospore with opaque inclusion (arrow). Slide $1477, \times 3000$. 5. Section of cell with two encysted zoospores (arrows) and dense protoplasmic contents beneath $(P)$ that have passed into the cell. Slide 1477 , $\times 1500.6$. Detail of zoospore protoplast inside cell wall (C); note the dense inclusion (arrow). Slide $1477, \times 3000$. 7. Section showing mature zoosporangium with discharge papilla protruding through cell wall. Note dense granular material beneath zoosporangium. Slide $1478, \times 1000$. 8. Detail of discharge papilla showing thickened tip (arrow). Slide $1478, \times 3000$. 9. Palaeonitella cranii rhizoidal cell showing two zoosporangia. Slide 1478 , $\times 300$. 10. Two partially collapsed zoosporangia with papilla projecting through cell wall. Compare granular material beneath zoosporangia with that in Fig. 7. Slide 1478, $\times 1000$. 
Taylor et al.: Devonian Fungi
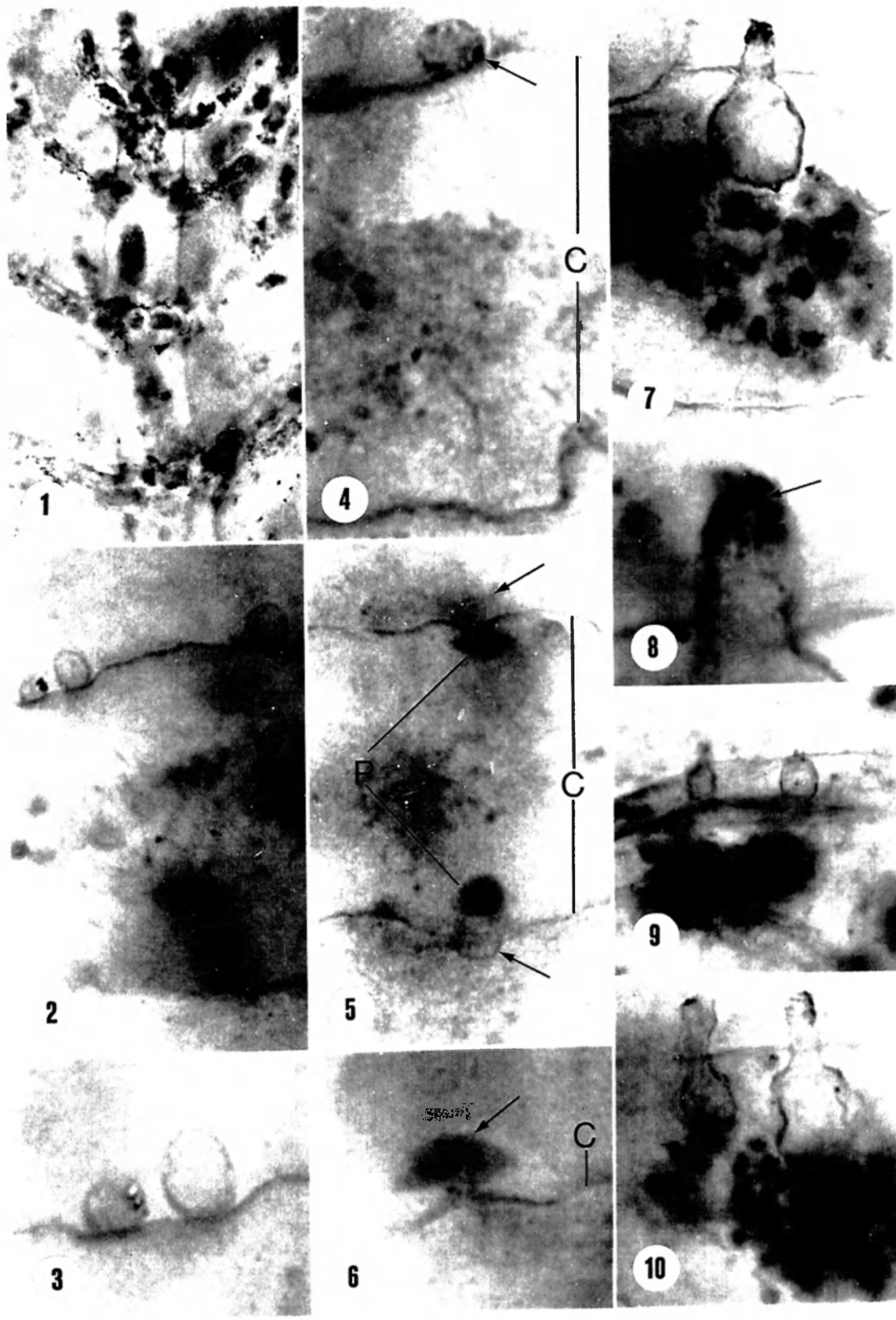

\section{4}
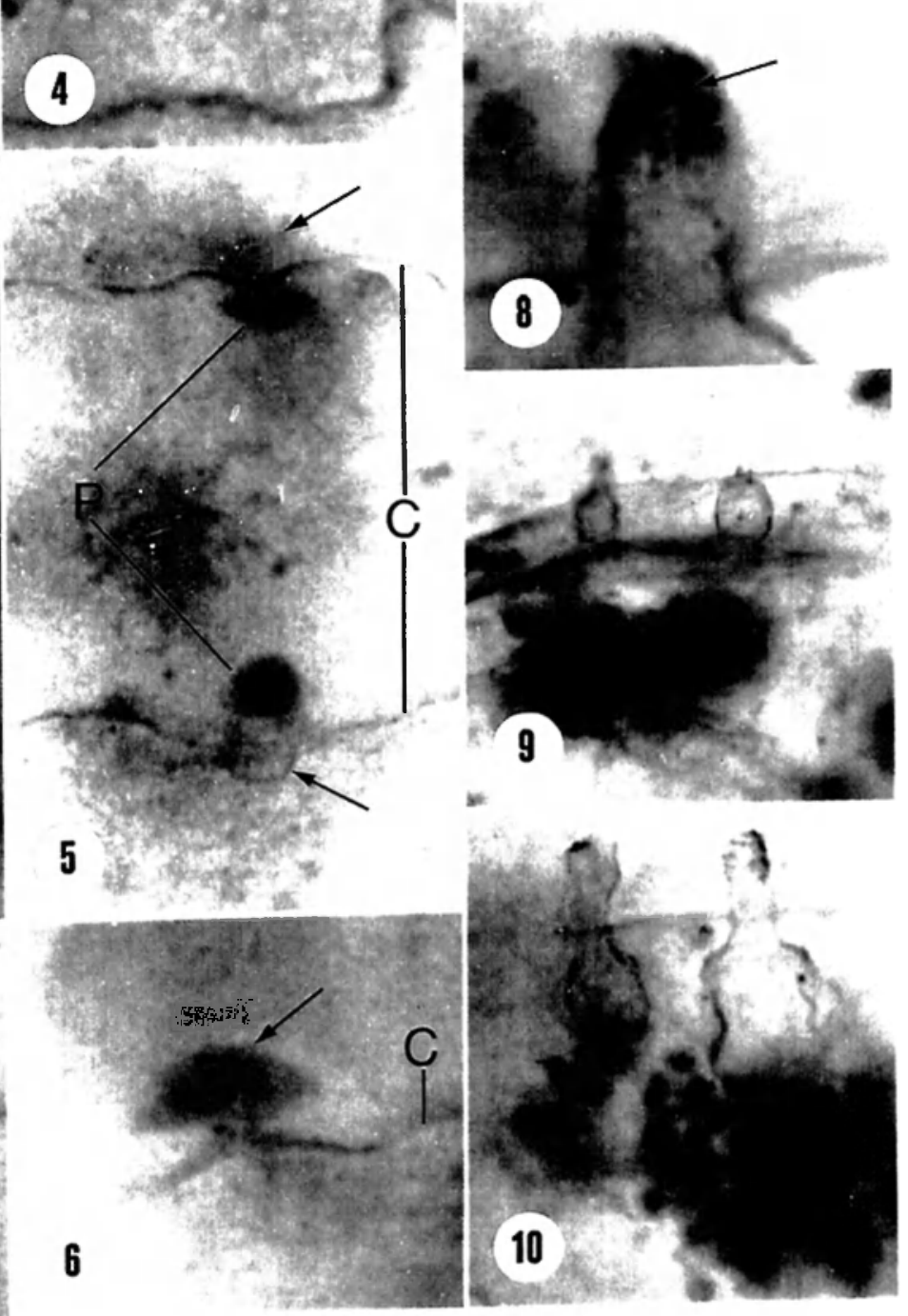
zoospore is a dense spherical-lenticular structure that we interpret as the protoplast of the fungus that has passed into the host cell from the zoospores (FIG. 5). Although it has not been possible to identify a penetration tube between the zoospore and the protoplast, the constant association of the zoospore outside the cell wall and the dense material inside suggests that this structure is in fact the protoplast of the fungus. In some specimens the protoplast possesses a central refractive body (FIGS. 5, 6) which is identical to that structure seen in some zoospores (FIG. 4). Further strengthening the relationship between the zoospore and the protoplast is the fact that when a refractive body is present it is only displayed in one of the structures (FIG. 5).

The most conspicuous phase of Milleromyces is the flask-shaped zoosporangium (FIG. 7). These may be solitary within a cell or occur in clusters (FIGs. 9, 10). Each zoosporangium may be up to $60 \mu \mathrm{m}$ long and consists of a swollen basal portion and a single, narrow discharge tube that characteristically penetrates the host cell (FIGS. $7,10)$. The inflated portion of the zoosporangium is up to $15 \mu \mathrm{m}$ in diam, tapering to a discharge papilla which is about $4 \mu \mathrm{m}$ in diam (FIG. 7). The tube is inoperculate although the outer orifice often appears to have a slightly thickened collar (FIGs. 7, 8, 10). We believe that this thickened region is the result of the wall of the tube folding back upon itself during the release of the zoospores. All of the zoosporangia are empty; in some the swollen portion may be partially collapsed (FIG. 10). It is probable that some of the zoosporangia are immature and have either not formed zoospores (FIG. 15), or they simply can not be resolved because of the lack of contrast in the rock matrix (FIG. 12).

Extending from the base of each zoosporangium is a small protrusion that represents the attachment point of the rhizomycelium (FIGs. 7, 11). In some zoosporangia this structure appears in a slightly lateral position (FIG. 12), and is sometimes prominent (FIG. 14). The rhizoidal system in Fig. 12 shows a dichotomy close to the point of attachment. In a few specimens it has been possible to detect the outline of the overall nature of the rhizomycelium within the cell lumen (FIG. 9). In these specimens the cell often appears filled with a fimbriate material (FIG. 9). Generally, however, the hyphae are too indistinct to determine the extent of the rhizomycelium within the cell. In one specimen the rhizoidal system can only be traced for approximately $200 \mu \mathrm{m}$ owing to the delicate and translucent nature of the mycelium (FIGs. 13, 14). Hyphae are approximately $1 \mu \mathrm{m}$ in diam near the attachment point on the base of the zoosporangium, repeatedly branching and becoming finer deeper within the cell lumen.

Comparison. - The zoosporangium of Milleromyces is like that of several eucarpic chytrids, including some members of the Entophlyctaceae such as Endochytrium. Some species of this genus are parasitic on certain green algae, including charophytes, as well as being saprophytic on cellulose. Several species share a number of features in common with Milleromyces including the general size and shape of the thallus and occasional lateral position of the rhizomycelium. One major difference between the two is the operculate nature of the zoosporangium in Endochytrium species. An even greater morphological similarity can be seen between Milleromyces and several species of Entophlyctis. These include the inoperculate nature of the zoosporangium and peripherally located rhizomycelium. Both living genera are reported as being weakly parasitic or saprophytic on green algae (Karling, 1977).

FIGs. 11-20. Fossil fungi and Palaeonitella cranii. Milleromyces rhyniensis (FIGs. 11-15) and Lyonomyces pyriformis (FIGs. 16-20). 11. Zoosporangium with discharge papilla protruding through cell wall (C). Arrow indicates attachment point of rhizomycelium. Slide $1478, \times 1000.12$. Mature zoosporangium with papilla extending through cell wall. Arrow indicates attachment point of rhizoidal system. Slide $1487, \times 1000.13$. Base of zoosporangium; insert shows rhizoid attachment. Compare with FIG. 14 which is at a different focal plane. Slide $1487, \times 1000.14$. Base of zoosporangium showing attachment of rhizoidal system. Compare with Fig. 13. Slide $1487, \times 1000.15$. Possible immature zoosporangium with discharge papilla (arrow). Slide $1487, \times 1000$. 16. Transverse section of Palaeonitella cranii cell with numerous Lyonomyces pyriformis thalli attached to surface. Insert shows thalli in FIG. 18. Slide 2261, $\times 200.17$. Palaeonitella cranii with attached thalli. Insert shows forms in FrG. 19. Slide $2261, \times 200.18$. Two thalli with collapsed rhizoids. Arrow indicates probable exit site. Slide $2261, \times 1000$. 19. Several thalli embedded in dense material that may represent a gelatinous coating on the cell wall surface. Bulb-like tip (arrow) may represent the operculum. Slide $2261, \times 1000.20$. Two thalli; the upper one with a bulbous tip. Slide $2261, \times 1000$. 

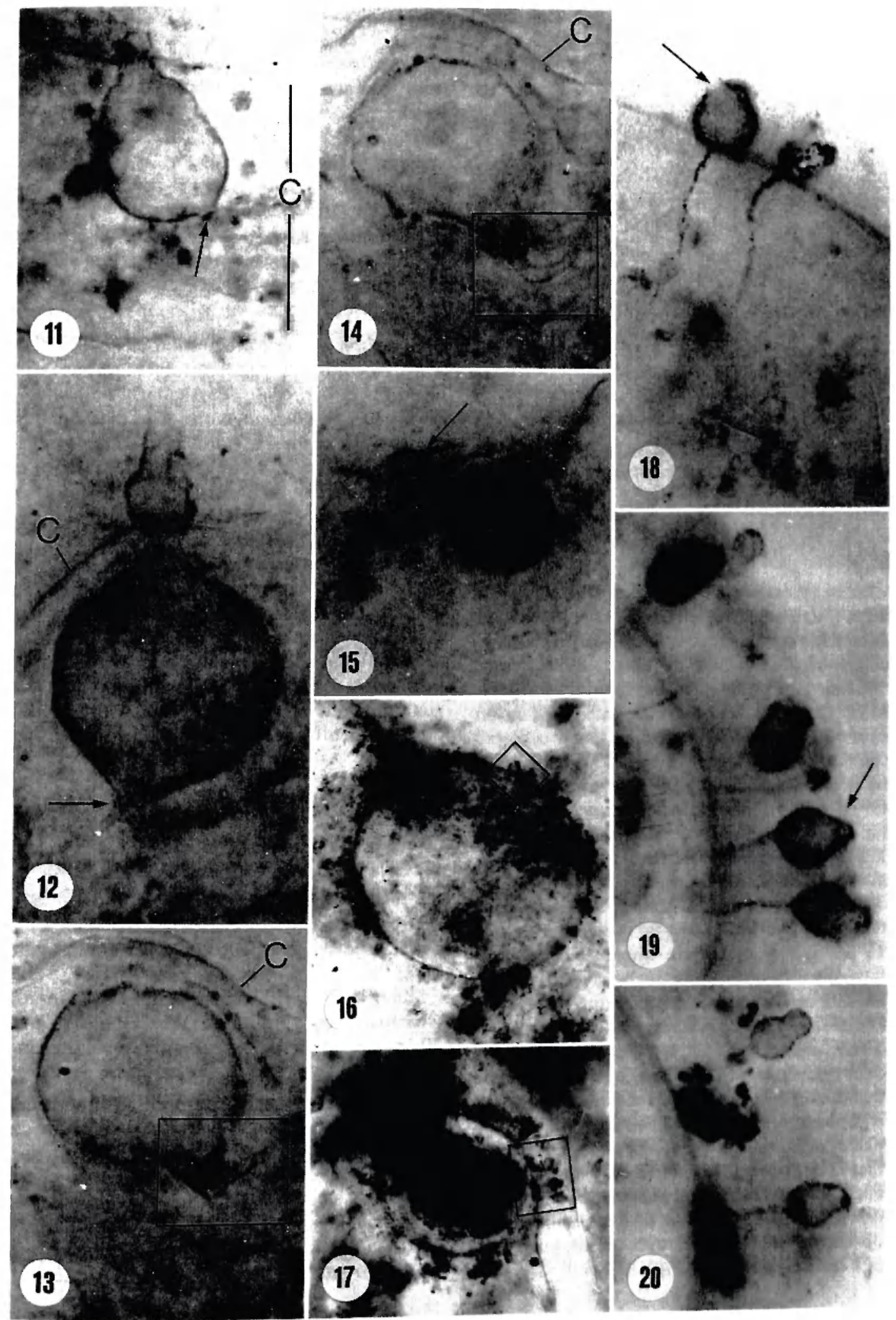
Lyonomyces Taylor, Hass et Remy, gen. nov. (Diagnosis same as for type species.)

Lyonomyces pyriformis Taylor, Hass et Remy, sp. nov.

Figs. 16-20

Smooth walled, globose to pyriform thallus up to $15 \mu \mathrm{m}$ long with distal end of some bulb-like; base spherical with single, unbranched rhizoid approximately $0.5 \mu \mathrm{m}$ in diam extending from median position on base, rhizoid extending into cell; other features of the zoosporangium unknown.

HOLOTYPE. Specimen in slide 2261 , in the collection of W. Remy. Fig. 19 (arrow) in this paper.

PARATYPE. Specimen in slide 2261 in the above collection; Figs. 16-18, 20 in this paper.

Collection locality. Rhynie, Aberdeenshire, Scotland.

Age. Lower Devonian.

StratigraPHic POSITION. Siegenian.

ETYMoLoGY. The generic name Lyonomyces is proposed in honor of A. G. Lyon for his many significan paleobotanical contributions and continuing interes in the Rhynie Chert flora; pyriformis refers to the general shape of the thallus.

COMmentary. Lyonomyces pyriformis is always found attached to the outer surface of $\mathrm{Pa}$ laeonitella cell walls (FIGs. 16, 17). In general the cells to which this fungus is attached range from $100-165 \mu \mathrm{m}$ in diam. In the majority of specimens the fungi appear to be embedded in an opaque material that covers the outer cell wall (FIGS. 19, 20). In some regions this material may be nearly $30 \mathrm{um}$ thick and topographically conforms to the gelatinous sheath material that is produced by certain living charophytes (Tappan, 1980). All of the specimens of Lyonomyces are at approximately the same stage of development, although a few minor differences were noted. Each thallus is spherical to slightly elongate and up to $15 \mu \mathrm{m}$ in the maximum dimension. In some specimens the distal end is slightly rounded (FIGs. $18,19)$; in others the tip is bulbous with the tip end nearly as large as the remainder of the thallus (FIG. 20). In one specimen the distal end appears to be bilobed (FIG. 18). There is some suggestion that the tip of the thallus is the point from which zoospores are liberated. This is based on the caplike organization of the distal end, and the fact that in one specimen where the tip appears to be open, the rhizoid is collapsed as if no longer functional (FIG. 18). In a few of the specimens the tip end of the thallus is translucent, suggestive of a discharge site (FIG. 19).
Regardless of the general morphology, specimens of Lyonomyces possess a delicate unbranched rhizoid that extends from the base of the thallus and either extends into, or completely penetrates the algal cell wall (FIGs. 18-20). The maximum diameter of the rhizoid where it is attached to the spores is $0.5 \mu \mathrm{m}$. It is impossible to state with certainty whether this rhizoid represents an initial stage of a rhizomycelium, or the complete rhizoidal system. However, since none has been observed branching we believe that $L$. pyriformis is characterized by a single, unbranched rhizoid.

Comparison. - There are numerous aquatic fungi with the same morphological features as those noted for $L$. pyriformis. Particularly noteworthy are species of Rhizophydium. The overall comparative size of the fossil and living thallus might exclude some taxa; however, in the absence of other potentially diagnostic features, the association with the charophyte Palaeonitella might be of value in more accurately determining the systematic affinities of this fungus. Interestingly, Sparrow (1960) records more than a dozen living fungi that have been found on charophytes, and this number is no doubt appreciably larger today. As additional specimens are discovered it may be possible to expand the description of this fungus to include other features that will more accurately identify the systematic position of $L y o$ nomyces.

Krispiromyces Taylor, Hass et Remy, gen. nov. (Diagnosis same as for type species.)

Krispiromyces discoides Taylor, Hass et Remy, sp. nov.

FIGs. 21-24, 27

Extramatrical, holocarpic, smooth-walled eucarpic, disc-shaped thallus up to $45 \mu \mathrm{m}$ in diam, zoosporangium operculate with small cap-like discharge papilla, rhizoidal system of centrally located primary, intramatrical apophysis up to $20 \mu \mathrm{m}$ in diam, secondary apophyses smaller and attached to hyphae $1.5 \mu \mathrm{m}$ wide, or narrowed into isthmus; zoospores $4 \mu \mathrm{m}$ in diam. Resting spores unknown.

HOLOTYPE. Specimen in slide 1359, Paleobotanical Slide Collection, W. Remy; Figs. 21-23 of this paper.

PARATYPE. Specimen in slide 1359 in the above collection; Figs. 24, 27 of this paper.

Collection locality. Rhynie, Aberdeenshire, Scotland. 
AgE. Lower Devonian.

StRATIGRAPHIC POSITION. Siegenian.

ETYMOLOGY. The generic name Krispiromyces is proposed in honor of Dr. Kris A. Pirozynski for his continuing interest and many contributions to paleomycology. The specific epithet discoides refers to the characteristic disc-shape of the thallus.

COMMENTARY. This fungus appears to be associated consistently with large Palaeonitella cells, typically in the $300 \mu \mathrm{m}$ size range (FIG. 21). Unlike the condition in Lyonomyces, there are far fewer fungi associated with these cells (FIGs. 21, 25,26 ). The zoosporangium in this form is more deeply embedded in the outer coating layer of the alga, with just the operculate cap appearing to penetrate the surface. Specimens of Krispiromyces consist of a disc-shaped thallus up to 40 $\mu \mathrm{m}$ in diam which is thickest in the center, gradually tapering to the periphery (FIGs. 22, 23). In a few specimens the zoosporangium is irregular and partially collapsed suggesting that zoospores were shed prior to fossilization. Arising from the center of the zoosporangium is a small, slightly thickened papilla up to $12 \mu \mathrm{m}$ in diam (FIGs. 22, 24). At the distal end is a beak-like projection. We interpret the slight thickening on the lateral side of the papilla as evidence that Krispiromyces possesses an operculate zoosporangium. In one specimen it was possible to identify zoospores within the sporangium (FIG. 27). They are approximately $4 \mu \mathrm{m}$ in diam and each has a single refractive inclusion (FIG. 27).

Attached in a medial position to the lower surface of the disc-shaped zoosporangium is a large, primary intramatrical apophysis up to 20 $\mu \mathrm{m}$ in diam (FIGS. 22, 23). Extending from this enlarged hypha in various directions are other segments of the rhizoidal system that include globose to elongate structures that we interpret as secondary apophyses (FIGs. 22, 23). These inflated hyphae are attached to each other by smaller, narrow $(1.5 \mu \mathrm{m})$ swellings or are narrowed into a restricted isthmus (FIG. 23).

Comparison. - Based principally on zoosporangium and thallus morphology Krispiromyces shares a number of features with several living eucarpic, apophysate taxa. One of these is Phlyctochytrium, a common parasite of fresh water algae. Although the genus is generally regarded as inoperculate, Karling (1977) notes that neither the presence of an apophysis nor operculum on the zoosporangium is a consistent feature of the taxon. Another extant taxon that shares features with Krispiromyces is Catenochytridium (Berdan, 1939). In this operculate, holocarpic form, compound apophyses are common, as is the case in several members of the Ectophyctaceae. All of these extant forms have been reported as parasites of numerous fresh water algae, including members of the Characeae (Sparrow, 1960). While it is doubtful that there will ever be a sufficient suite of morphological features available to compare fossils directly with modern taxa, the presence of many comparable morphological structures indicates that there was considerable diversity within the aquatic fungi prior to the Lower Devonian age of the Rhynie Chert.

\section{DISCUSSION}

In the absence of an obvious host response or a particular suite of characters that can be used to identify the fungus, it is difficult to evaluate the particular type of interaction that existed between the fungus and its host. This is especially difficult with fossil material where the number of specimens is characteristically very small, and the life history of the fungus is incompletely known. For the fungi described to date from the Rhynie Chert, most were probably saprobes, however, at least one of the fungi associated with Palaeonitella was parasitic (Taylor et al., 1992a). This can be deduced from the presence of several abnormally large cells intermixed with normal ones along the axis of Palaeonitella (FIGs. 25, 26). These large cells, some of which reach diameters in excess of $300 \mu \mathrm{m}$, are associated with both Milleromyces and Krispiromyces. One group of aquatic fungi that typically causes cell hypertrophy is the Plasmodiophoromycetes (MooreLandecker, 1982). Milleromyces shares several zoosporangial features with species of Woronina and Sorodiscus, two genera of common Plasmodiophoromycetes, including the size and shape of the zoosporangium, and the response by the host. Interestingly, these fungi have been described as producing hypertrophied cells in several algae, including species of Chara (Karling, 1928). In Chara all cells of the plant appear to be susceptible, but those of the stems and leaves are more often attacked. There is an extensive literature on the physiological interaction between parasite and host in which excessive cell and tissue growth constitutes the primary symptom. In extant plants, both hypertrophy (excessive growth due to the enlargement of individual 

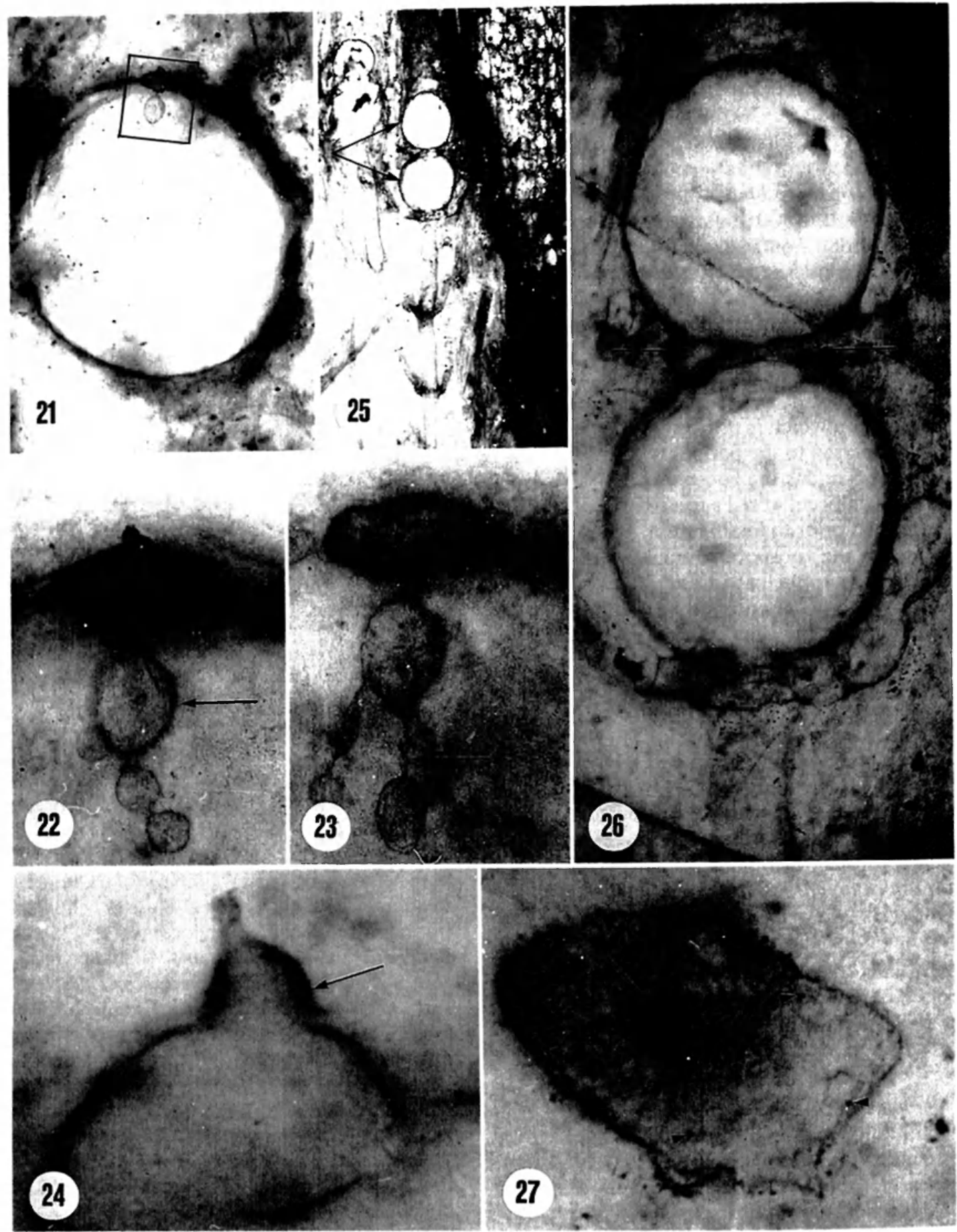

Figs. 21-27. Fossil fungi and Palaeonitella cranii. 21-24, 27. Krispiromyces discoides. 21. Palaeonitella cranii cell with fungus penetrating cell wall (insert); rhizomycelium extends into the cell lumen. Slide 1359, $\times 150.22$. Detail of fungus showing the discoid thallus (zoosporangium) and primary (arrow) and secondary apophyses of the rhizomycelium. Slide $1359, \times 600.23$. Different focal plane from Fig. 22 showing primary and secondary apophyses, and narrow hypha (arrow) between. Slide 1359, $\times 600.24$. Lateral view of zoosporangium with small 
cells) and hyperplasia (excessive growth due to the increased division of cells) may be the result of various growth regulators (Pegg, 1984). However, identifying those responsible has been a difficult task. Although physiological interactions will never be elucidated in fossil examples, the fact that identical symptoms found in modern plants are evident in 400-million-year-old organisms provides an indirect method of assessing the antiquity of certain kinds of hostparasite interactions.

One feature that would appear to eliminate Milleromyces and Krispiromyces as Devonian members of the Plasmodiophoromycetes is the eucarpic thallus in these fossils as compared to the holocarpic form in all extant members (Karling, 1968). A second character present in the modern members that has not been observed in the fossils is the plasmodial stage. If these fossils were to be included in the modern class then it assumes that during their evolution there have been major changes in thallus morphology, life cycle and the nutritional mode.

In addition to the production of hypertrophied cells, Karling (1928) reports that in modem species of Chara the parasite also appears to stimulate the production of increased numbers of large starch grains in the plastids. Although we cannot test this assumption, it is possible that the consistent occurrence of large granular bodies in the infected Palaeonitella cells (Frgs. 7, 10) signals a similar response in the alga.

The Rhynie Chert fungi described to date not only underscore the antiquity of certain groups, but also indicate a new type of morphological host response that can be recognized in other fossil assemblages throughout geologic time. Identifying major groups of fungi in the fossil record continues to be a difficult endeavor due to the small number of specimens. The ability to recognize host responses in plants opens the possibility of not only tracing the evolutionary adaptations of fungi, but also for exploring the interactions of ancient organisms with other members of the paleoecosystem.

\section{ACKNOWLEDGMENTS}

We are indebted to Drs. Martha J. Powell, Donald J. S. Barr, Terry W. Johnson, Jr. and Kris A. Pirozynski for their valuable comments about these Devonian fungi. This research was supported in part by funds from the National Science Foundation (DPP-8702337). the Deutsche Forschungsgemeinschaft (Re 200/16-1) and the Deutscher Akademischer Austausch Dienst.

\section{LITERATURE CITED}

Barr, D. J.S. 1980. An outline for the reclassification of the Chytridales, and for a new order, the Spizellomycetales. Canad. J. Bot. 58: 2380-2394.

- 1984. The classification of Spizellomyces. Gaertneriomyces, Triparticalcar, and Kochiomyces (Spizellomycetales. Chytridiomycetes). Canad. J. Bot. 62: 1171-1201.

Berdan, H. 1939. Two new genera of operculate chytrids. Amer. J. Bot. 26: 459-463.

Edwards, D. S. 1986. Aglaophyton major, a nonvascular land-plant from the Devonian Rhynie Chert. J. Linn. Soc., Bot. 93: 173-204.

, and A. G. Lyon. 1983. Algae from the Rhynie Chert. J. Linn. Soc. Bot. 86: 37-55.

Karling, J. S. 1928. Studies in the Chytridales III. A parasitic chytrid causing cell hypertrophy in Chara. Amer. J. Bot. 15: 485-495.

- 1968. The Plasmodiophorales. Hafner Publishing Co., New York.

- 1977. Chytridiomycetarum Iconographia. Lubrecht and Cramer, Vaduz, Liechtenstein.

Kenrick, P, W. Remy, and P. R. Crane. 1991. The structure of water-conducting cells in the enigmatic early land plants Stockmansella langii Fairon-Demaret, Huvenia kleui Hass et Remy and Sciadophyton sp. Remy et al. 1998. Argumenta Palaeobot. 8: 179-191.

Kidston, $R_{\text {, and }}$ W. H. Lang. 1921. Old Red Sandstone plants showing structure, from the Rhynie Chert bed, Aberdeenshire. Part 5. The thallophyta occurring in the peat-bed: the succession of the plants throughout a vertical section of the bed, and the conditions of accumulation and preservation of the deposit. Trans. Roy. Soc. Edinburgh 52: 855-902.

Miller, C. E. 1976. Substrate-influenced morphological variations and taxonomic problems in freshwater, posteriorly uniflagellate Phycomycetes. Pp. 469-487. In: Recent advances in aquatic mycol$o g y$. Ed., E. B. Garth Jones. Elek Science, London.

Moore-Landecker, E. 1982 . Fundamentals of the fungi. 2nd ed. Prentice Hall, New Jersey.

exit papilla and thickened wall (arrow). Slide 1359, $\times 1500.25$. Longitudinal section of Palaeonitella cranii showing several nodes and hypertrophied cells (arrows). Slide $1385, \times 30.26$. Two cells showing extensive enlargement when compared with normal cells at base, and internodal cortical cells (arrows). Slide $1385, \times 150$. 27. Polar view of zoosporangium showing exit papilla (arrow). Zoospores are present inside; each characterized by an opaque inclusion (arrowheads). Slide 1359, x 1500. 
Pegg, G. F. 1984. The role of growth regulators in plant disease. Pp. 29-48. In: Plant diseases-infection, damage and loss. Eds., G. J. Jellis and R. K. S. Wood. Blackwell Scientific Publ., London.

Remy, W., and H. Hass. 1991 a. Kidstonophyton discoides nov. gen., nov. spec., ein Gametophyt aus dem Chert von Rhynie (Unterdevon, Schottland). Argumenta Palaeobot. 8: 29-45.

-, and -. 1991b. Langiophyton mackiei nov. gen., nov. spec., ein Gametophyt mit Archegoniophoren aus dem Chert von Rhynie (Unterdevon, Schottland). Argumenta Palaeobot. 8: 69117.

-, and R. Remy. 1980. Lyonophyton rhyniensis nov. gen. et sp. nov. spec., ein Gametophyt aus dem Chert von Rhynie (Unterdevon, Schottland). Argumenta Palaeobot. 6: 37-72.

Sparrow, F. K. 1960. Aquatic Phycomycetes. University of Michigan Press, Ann Arbor.

Tappan, H. 1980. The paleobiology of plant protists. W. H. Freeman, San Francisco.

Taylor, T. N., W. Remy, and H. Hass. 1992a. Parasitism in a 400 -million-year-old green alga. $\mathrm{Na}$ ture 357: 493-494.

$\longrightarrow$, and $-1992 \mathrm{~b}$. Fungi from the Lower Devonian Rhynie Chert: Chytridiomycetes. Amer. J. Bot. (In press)

Accepted for publication August 20, 1992 